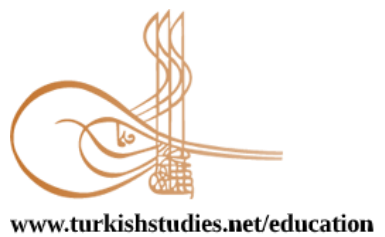

Turkish Studies - Educational Sciences

\title{
Yabancı Dil Olarak Türkçe Öğretiminde Kullanılan Ders Kitaplarındaki Uyarlanmış Metinlerin Uyarlanma Durumları: Yeni Hitit Örneği ${ }^{*}$
}

\author{
Adaptation Of Adapted Texts in Textbooks Used in Teaching Turkish As A Foreign Language: New \\ Hitit Example
}

\author{
Ceylan Ayar ${ }^{* *}$ - Berker Kurt ${ }^{* * *}$
}

\begin{abstract}
It is known that literary texts used to improve reading skills in teaching Turkish as a foreign language are included in textbooks. While advanced learners can easily grasp the original literary texts, the beginning and middle level learners have difficulty understanding these texts because they do not have enough linguistic skills. Therefore, in order to ensure that these literary texts are properly included in textbooks, they must be adapted to the level within the framework of certain methods and criteria. The aim of the study is to examine the adapted texts that are used in textbooks prepared for teaching Turkish as a foreign language in terms of their compliance with the text adaptation criteria. The study is based on document review from qualitative research methods. Prior to the examination, Turkish textbook for foreigners the adapted texts in the New Hitit Turkish Teaching Kit B1 textbook were determined, the original sources of the adapted texts were reached and a text evaluation tool containing the text adaptation criteria was prepared. New Hitit Turkish Teaching Kit A1A2 for foreigners and New Hitit Turkish Teaching Kit B1 for foreigners are based on grammar in the textbook for the adaptation process in the text evaluation tool. At the end of the review, the frequency and percentage values of the transactions are calculated and the rates of the transactions in the adapted texts are presented. When we look at the proportion of the text adaptation operations on the adapted texts in the new Hitit 2 book, it is concluded that the most lexical simplification was done. Syntactic simplification and expansion operations were found to be almost identical.
\end{abstract}

Structured Abstract: There have been many changes in the process of teaching a language as a foreign language from the beginning of its adventure to the present day. Texts are the most basic elements that do not lose their importance in this process of change and form the infrastructure of language teaching. In spite of changes in terms, needs, methods and techniques, there have always been texts somewhere in the language teaching.

\footnotetext{
* Bu çalışma "Yabancı Dil Olarak Türkçe Öğretiminde Kullanılan Uyarlanmış Metinlerin Uyarlanma Durumları Üzerine Bir İnceleme" adlı yüksek lisans tezinden üretilmiştir.

** Öğretim Görevlisi, Akdeniz Üniversitesi, TÖMER.

Lecturer, Akdeniz University, Turkish Teaching Application and Research Center.

ORCID 0000-0002-2951-5302

ceylanayar2810@gmail.com

**** Dr. Öğr. Üyesi, Akdeniz Üniversitesi Eğitim Fakültesi Türkçe ve Sosyal Bilimler Eğitimi Bölümü.

Asst. Prof. Dr. Akdeniz University, Faculty of Education, Department of Turkish \& Social Sciences Education

ORCID 0000-0003-4788-0909

berkerakdeniz@gmail.com

Cite as/ Atıf: Ayar, C. \& Kurt, B. (2020). Yabancı dil olarak Türkçe öğretiminde kullanılan ders kitaplarındaki uyarlanmış metinlerin uyarlanma durumları: yeni hitit örneği, Turkish Studies - Education, 15(3), 1521-1536. https://dx.doi.org/10.29228/TurkishStudies.43341

Received/Geliş: 03 May/Mayıs 2020

Accepted/Kabul: 20 June/Haziran 2020

Copyright $(C)$ INTAC LTD, Turkey

Checked by plagiarism software

Published/Yayın: 25 June/Haziran 2020

CC BY-NC 4.0
} 
Güneş (2013) grouped the texts used in teaching as literary texts, produced texts, original and special texts based on the language teaching approaches developed in recent years. Original texts have started to take place in teaching in line with cognitive approach. With this approach; the texts such as newspapers, letters, news, novel summaries, poems, posters, recipes, biographies, etc. are very useful in terms of improving the language skills of the target learners and ensuring permanence in these skills. Yücel and Erişek (2002) classified the types of texts in different ways by stating that literary texts should be used in addition to artificial and fictional texts in language teaching.

In the textbooks used in teaching Turkish as a foreign language, original and adapted texts are often included. While the advanced learner can easily understand the original text, it is necessary to bring the original text to the level that the target learners can understand, considering that the beginning and middle level will have difficulty understanding the text (Ak and Aksu, 2016).

The use of literary texts will enable the introduction of Turkish language, literature and culture to the world, the development of the target learner's mental and linguistic skills, the teaching of values, the development of imagination, and the increase of motivation. As it reflects everyday life, the texts that offer a natural material to language teaching provide many possibilities for developing vocabulary and sentence knowledge, grammar workspace and writing, effective reading and speaking skills (Ayhan and Arslan, 2014; and Şavlı and Ermağan, 2015).

Using texts directly in language, especially in Foreign Language Teaching, may not be pedagogically appropriate. In this respect, it is of great importance to create the materials to be used in language teaching and to examine these materials in terms of various criteria (Nurlu and Kaya, 2017) and to perform the processes such as simplification and adaptation by linguistic methods. Dilidüzgün (1995) states that it is necessary to arrange the texts according to the objectives of the course in advance by taking care not to lose their original structures. Similarly, Durukan and Bayraktar (2016) emphasize that texts must be adapted by authors according to text adaptation criteria before textbooks are prepared.

In this study, it was aimed to examine the adapted texts in textbooks used in teaching Turkish as a foreign language according to the adaptation criteria. For this purpose, the problem and sub-problem sentences of the study are as follows:

How are the adapted texts in the textbooks adapted for teaching Turkish as a foreign language?

1. What is the case of syntactic simplification in adapted texts?

2. What is the case of lexical simplification in adapted texts?

3. What is the case of expansion in adapted texts?

The model of the study is document analysis from qualitative research methods. The document of the study is the Yeni Hitit Turkish (B1) teaching set for foreigners. In order to examine the adaptation status of the adapted texts in the said document, the text adaptation criteria were first investigated.Simplification criteria which is created by Sandom (2013) based on the work of Mountford (1976), Anderson and Davidson (1988), Yano, long and Ross (1994), Kim and Snow (2009) and the stages determined by Siddhartan (2004) were adapted to Turkish by Özmen (2019) and a classification was created. The text evaluation tool used in the study was prepared in line with this classification.

In Yeni Hitit (B1) teaching set for foreigners, the rate of implementation of syntactic simplification in adapted texts is $23.8 \%$. Among these, the operation "separating / removing / replacing noun, adjective and adverbial sentences" ( $\mathrm{F}=10,20.8 \%)$ was the most performed.

The implementation rate of lexical simplification in adapted texts is $51.7 \%$. It is observed that the process of "deleting words and sentences that complicate the expression and lengthen the sentence" $(\mathrm{F}=58$, $54.7 \%$ ) is frequently used in these processes.

The rate at which expansion is applied to all texts is $24.9 \%$. Among the expansion processes, the most performed process is "completing the reductions by rewriting over again" $(\mathrm{F}=26,51 \%)$.

It was concluded that the most 'lexical simplification' was done in adapted texts when the rates of the implementations were compared. The 'syntactic simplification' and 'expansion' implementations are almost identical. The fact that lexical simplification has been widely applied reveals that there are over-level words 
and groups of words in texts, and that lexical modification, deletion or rewriting is necessary to make them appropriate to the level.

Based on this result, the texts that will be included in the teaching and reading books of Turkish as a foreign language should be created by complying with the text selection criteria and based on scientific criteria. The proliferation of these and similar studies will enable the field specialists to concentrate on the subject; with the text adaptation criteria to be developed by the experts, the standard of adaptation or simplification will be improved, and the purposefulness of the texts adapted for teaching will increase.

Keywords: Teaching Turkish, Teaching Turkish As A Foreign Language, Reading Skill, Adaptation Criteria, Textbook.

Öz: Yabancı dil olarak Türkçe öğretiminde okuma becerisini geliştirmek üzere faydalanılan yazınsal metinlere ders kitaplarında yer verildiği bilinmektedir. İleri düzeydeki öğreniciler özgün olarak sunulan yazınsal metinleri kolaylıkla kavrayabilirken başlangıç ve orta düzey öğrenicileri yeterli dilsel edince sahip olmadıkları için bu metinleri kavramakta güçlük çekmektedirler. Dolayısıyla bu yazınsal metinlerin ders kitaplarında uygun bir şekilde yer alabilmesini sağlayabilmek için belirli yöntemler ve ölçütler çerçevesinde düzeye uygun hâle getirilmesi gerekmektedir. Bu düşünceden yola çıkılarak yabancı dil olarak Türkçe öğretimi için hazırlanmış ders kitaplarında kullanılmakta olan uyarlanmış metinlerin, metin uyarlama ölçütlerine uygunluğu açısından incelenmesi çalışmanın amacını oluşturmaktadır. Çalışma, nitel araştırma yöntemlerinden doküman incelemesine dayanmaktadır. Yapılan inceleme öncesinde, Yeni Hitit Yabancılar İçin Türkçe B1 öğretim setindeki uyarlanmış metinler belirlenmiş, uyarlanmış metinlerin özgün kaynaklarına ulaşılmış ve metin uyarlama ölçütlerini içeren metin değerlendirme aracı hazırlanmıştır. Oluşturulan metin değerlendirme aracındaki uyarlama işlemleri için Yeni Hitit Yabancılar İçin Türkçe A1-A2 ve Yeni Hitit Yabancılar Icçin Türkçe B1 öğretim setinde yer alan dil bilgisi sıralanışı temel alınmıştır. İncelemenin sonunda yapılan işlemlerin frekans ve yüzde değerleri hesaplanarak uyarlanmıș metinlerdeki işlemlerin oranları sunulmuştur. Yeni Hitit Yabancılar İçin Türkçe B1 ders kitabı ve çalışma kitabında yer alan uyarlanmış metinler üzerinde yapılan metin uyarlama işlemlerinin oranlarına bakıldığında en çok sözlüksel sadeleştirme işleminin yapıldığ sonucuna ulaşılmıştır. Sözdizimsel sadeleştirme ve genişletme işlemlerinin ise hemen hemen aynı oranda olduğu görülmüştür.

Anahtar Kelimeler: Türkçe Öğretimi, Yabancı Dil Olarak Türkçe Öğretimi, Okuma Becerisi, Metin Uyarlama Ölçütleri, Ders Kitabı.

\section{Giriş}

Bir dilin yabancı dil olarak öğretimi serüveninin başlangıcından günümüze kadarki sürecinde birçok değişimler yaşanmıştır. Zamanın, dönemin veya ülkelerin imkân ve şartları, insanların dil öğrenmedeki ihtiyaç farklılıkları, dilbilim ve eğitim bilimin getirdiği yeni yaklaşım, yöntem ve teknikler değişimlerin yaşanmasındaki temel etkenler olmuştur. Yabancı bir dildeki dinî ve diğer önemli metinlerin ana diline kazandırılmasının yeterli görüldüğü dil öğrenimi yetkinliğinden, binlerce kilometrenin saatler içinde kat edildiği, iletișim araçlarıyla farklı dil ve kültürdeki insanların birbirleriyle kolayca iletişim kurduğu ve dolayısıyla farklı dil yetkinliklerine sahip olunmasının gerekli olduğu bir dil öğretimi sürecine geçilmiş oldu. Diğer bir ifadeyle sadece okuma becerisinin yetkinliğinden, iletişim ortamında ihtiyaç duyulan okuma, dinleme, konuşma ve yazma becerilerine aynı oranda önem veren bütünleşik dil becerileri yetkinliği önem kazandı.

Bu değişim sürecinde önemini kaybetmeyen ve dil öğretiminin alt yapısını oluşturan en temel unsur metinlerdir. Şartlar, ihtiyaçlar, yöntem ve tekniklerdeki değişmelere rağmen dil öğretiminin bir yerinde mutlaka metinler olmuştur.

Metin, iletişimsel bir ortamda doğal bir dil kullanımı, kendine özgü birlik üst birimleri olan anlamsal-yapısal-iletişimsel bir varlıktır (Demircan 1990: 95). Yine Demircan'ın Wurderlich'ten (1983) aktardığına göre metin, tümcelerle ya da birbirine nedensel olarak bağımlı önermelerle 
gerçekleşen, sözlü ya da yazılı herhangi uzunlukta birleşik, anlamsal bir bütündür ya da "sonlu sayıda tümcenin bağdaşık dizisi"dir (Demircan 1990: 97). Metinler, farklı özellikleri veya işlevleri neticesinde farklı sınıflandırmalara tabi tutulmuştur. Örneğin, Yılmaz'a (2009: 7) göre iki temel metin türü vardır: Birincisi yazılış amaçları ve iletişim açısından metinler; ikinci ise işlevleri açısından metinlerdir. Birinci gruba bilgi, haber iletme amacını taşıyan, gerçek durumları değiştirmeden ifade eden metinler olan kullanımlık metinler ile yazarın yeniden düzenleme, seçme, sıralama yapmak suretiyle dili yeniden kurarak vücuda getirdiği kurmaca metinler girer. İkinci gruba ise anlatısal, şiirsel, söyleşimsel, öğretici, mesleki, uyarıcı, akademik/bilimsel, kılavuz, fantastik metinler ile basin metinleri girer.

Güneş (2013) son yıllarda geliştirilen dil öğretim yaklaşımlarına dayanarak öğretimde kullanılan metinleri edebî metinler, üretilmiş metinler, özgün ve özel metinler olarak gruplandırmıştır. Özgün metinler bilişsel yaklaşım doğrultusunda öğretimde yer almaya başlamıştır. $\mathrm{Bu}$ yaklaşımla birlikte gazete, mektup, haberler, roman özetleri, şiirler, afişler, yemek tarifleri, biyografiler $v b$. metinler, hedef kitlenin dil becerilerini geliştirmesi ve bu becerilerde kalıcılığın sağlanması açısından oldukça faydalıdır. Yücel ve Erişek (2002) ise dil öğretiminde yapay ve kurgu metinlerin yanı sıra yazınsal metinlerin kullanılması gerektiğini ifade ederek metin türlerini farklı açılardan tasnif etmişlerdir.

Yazınsal metinlerin kullanılması Türk dili, edebiyatı ve kültürünün dünyaya tanıtılmasının yanı sıra hedef kitlenin zihinsel ve dilsel becerilerinin gelişimini, değer öğretimini, hayal gücünün geliştirilmesini, motivasyonun artırılmasını sağlayacaktır. Gündelik hayatı yansıttığı için dil öğretimine doğal bir malzeme sunan metinler, kelime ve cümle bilgisi, dil bilgisi çalışma alanı ve yazma, etkin okuma ve konuşma becerilerini geliştirmeye yönelik birçok olanak sağlamaktadır (Arslan ve Ayhan, 2014; Şavlı ve Ermağan, 2015). Ayrıca yazınsal ürünlerin dil öğretiminde kullanılması, dilin doğru ve yararlı bir şekilde öğretilmesi hususunda oldukça önemli bir görev üstlenmektedir. Ancak metinleri dil, özellikle de yabancı dil öğretiminde doğrudan doğruya kullanmak pedagojik anlamda uygun olmayabilir. $\mathrm{Bu}$ açıdan dil öğretiminde kullanılacak materyallerin oluşturulması ve bu materyallerin çeşitli ölçütler açısından incelenmesi (Nurlu ve Kaya, 2017) ve sadeleştirme, uyarlama gibi işlemlerin dilbilimsel yöntemlerle yapılması büyük bir önem taşımaktadır. Dilidüzgün (1995) metinleri, özgün yapılarını kaybetmemelerine özen göstererek daha önceden dersin hedeflerine göre belirli bir oranda düzenlemek gerektiğini ifade eder. Benzer olarak Durukan ve Bayraktar (2016) da metinlerin ders kitapları hazırlanmadan önce yazarlar tarafından metin uyarlama ölçütleri gözetilerek uyarlanması gerektiğine vurgu yapmaktadır.

\section{Metin Uyarlama veya Sadeleştirme Ölçütleri}

Berardo’ya (2006) göre özgün metinler hedef kitleye sunulmadan önce, anlaş1labilirliği artırabilmek için uygun bir hâle getirilmelidir. Bunun temel yolu ise metinleri dil seviyesine göre basitleştirmektir. Ayrıca Berardo (2006) metindeki zor kelime ve yapıları çıkarmann metnin otantik yapısını bozabileceği kaygısıyla sadeleştirme yapılırken dikkate alınması gereken parametreleri üç maddede toplamaktadır. Bunlar: a) Dilde sadelik (dil bilgisel yapılar, kelime ögeleri, okunabilirlik) b)Bilişsel sadelik (yaş, eğitim, hedef kitlenin ihtiyaçları) c) Psikolojik uygunluk (Geleneksel sosyal normları takip ediyor mu?)

Kaynak metin içerisindeki, özellikle sözdizimsel, sözcüksel ve anlamsal unsurlar, çeşitli dilbilimsel işlemler yoluyla okuyucuların daha kolay anlayabileceği metinlere dönüştürülmektedir (Durmuş, 2013). Bu süreçte kaynak metindeki sözdizimsel, anlambilimsel ve sözcüksel yapılar, okuyucu hedef kitlenin niteliğine ve dil seviyesine göre değiştirilmektedir. belirtmiştir:

Bölükbaş (2015: 928) farklı kaynaklardan hareketle metin sadeleştirme ölçütlerini şu şekilde 
1. Sözcüksel değiştirme: Az kullanılan sözcük ya da ifadenin daha sık kullanılan sözcük ya da ifadeyle değiştirilmesi. a) Cümleden bazı sözcük ya da ifadelerin atılarak sözcüksel yoğunluğun azaltılması. b) Anlamayı kolaylaştırmak amacıyla cümleye yeni sözcük ya da ifadelerin eklenmesi.

2. Sözdizimsel değiştirme: a) Devrik cümlelerin kurallı hâle dönüştürülmesi ve cümledeki sözcüklerin ya da ifadelerin yeniden sıralanması. b) Uzun cümlelerin kısa cümlelere ve bağlı, sıralı ya da bileşik cümlelerin basit cümlelere dönüştürülmesi, yani cümlenin bölünmesi. c)Anlamayı kolaylaştırmak amacıyla ayrı cümlelerin sebep-sonuç, amaç-sonuç, zıtlık vb. anlamı taşıyan bağlaçlarla birleştirilmesi.

3. Sözcüksel-sözdizimsel değiştirme: a) Sözcük, ifade ve yapıların tekrarından kaçınarak metni küçültme. b)Yapısal ve anlamsal olarak karmaşık olan ifadeleri yeniden kurma. c)Cümledeki örtük anlatımları ya da anlaşılması zor yapıları açıklamak için metne eklemeler yapma.

4. Biçimsel değiştirme: Anlamayı kolaylaştırmak amacıyla bir paragrafın birkaç parçaya bölünmesi ya da bağlaçlar kullanılarak iki paragrafın birleştirilmesidir.

Specia'nın (2010) çalışmasında belirlediği sadeleştirme işlemleri ise şöyledir:

1. Sadeleştirilmiş olan yapıları korumak

2. Bilinmeyen veya karmaşık olan sözcüksel yapıları bilinen, daha az karmaşık olan sözcüksel yapılarla değiştirmek

3. Deyim ve bağdaştırma şeklindeki sözcük gruplarını; söylemin, konuşmanın anlamayı güçleştirecek bazı belirteçlerini/işaretleyicilerini değiştirmek

4. Sözdizimini kurallı yapı hâline getirmek

5. Edilgen yapılı cümleleri etken çatılı hâle getirmek

6. Cümleciklerin yerini değiştirmek veya karmaşık yapılar ise basit yapılara dönüştürmek

7. Cümleleri bölmek veya birleştirmek

8. Cümleleri veya cümlelerin bir kısmını düşürmek/atmak (aktaran Durmuş, 2013: 32)

Dil öğretimi için yapılan sadeleştirme işleminde genellikle sezgisel yaklaşımın daha yaygın olduğu düşünülmektedir. Öğretim elemanları ve kitap yayıncılarının sadeleştirme yaparken çoğunlukla bu yaklaşımı benimsedikleri görülmektedir (Crossley, Scott, Allen, Danielle ve Mcnamara, 2011). Durmuş ve Cihangir (2018: 693) ders kitaplarındaki metinlerde uygulanan sadeleştirme işlemlerinin sezgisel yolla yapıldığını belirterek şöyle sıralamıştır:

1. Eksiltmeler aracılı̆̆ıyla metnin hacminde yapıllan sadeleştirmeler;

2. Metin içi ilişkiler ve göndermeler çıkarılarak veya bu tür sözcüklere ve söz öbeklerine yer vermeyerek yapılan sadeleştirmeler;

3. Daha kapsamlı ve çok yönlü olabilecek içeriğin yaratacağı bilişsel yükü hafifletmek ve dil öğretimi etkinliklerinde kullanılabilecek alıştırmalara uygunluk sağlamak üzere, içeriği sınırlandırmaya dayalı sadeleştirmeler;

4. İçeriği, belirli ve sınırlı bir mesaj veya bilgi etrafinda oluşturarak yapılan sadeleştirmeler;

5. Düzey planlaması içinde öğretilecek yapılara odaklı ve onlarla sınırlı anlatım özelliklerini gözeten sadeleştirmeler.

Yabancı dil olarak Türkçe öğretiminde kullanılan ders kitaplarında genellikle özgün ve uyarlanmış metinlere yer verilmektedir. İleri düzeydeki hedef kitle özgün metinleri kolaylıkla anlayabilirken başlangıç ve orta seviyedekilerin metni anlamakta zorluk çekeceği göz önünde bulundurularak yararlanılacak olan özgün metnin hedef kitlenin anlayabileceği seviyeye getirilmesi gerekir (Ak ve Aksu, 2016). Dolayısıyla özellikle başlangıç ve orta düzey metinlerde kullanılacak olan metinlerin belirli ölçütlere dayanılarak uyarlanması gerekmektedir.

Bu çalışmada, yabancı dil olarak Türkçe öğretiminde kullanılan ders kitaplarında yer alan uyarlanmış metinlerin, uyarlama ölçütlerine göre incelenmesi amaçlanmıştır. $\mathrm{Bu}$ amaç doğrultusunda çalışmanın problem ve alt problem cümleleri şöyledir: 
Yabancı dil olarak Türkçe öğretimi ders kitaplarındaki uyarlanmış metinlerin uyarlanma durumları nasıldır?

1. Uyarlanmış metinlerdeki sözdizimsel sadeleştirme durumu nasıldır?

2. Uyarlanmış metinlerdeki sözlüksel sadeleştirme durumu nasıldır?

3. Uyarlanmış metinlerdeki genişletme durumu nasıldır?

\section{Yöntem}

\section{Çalışmanın Modeli}

Çalışmanın modeli nitel araştırma yöntemlerinden doküman analizidir. Doküman analizi, araştırılması hedeflenen olgu ya da olaylarla ilgili yazılı materyallerin analiz edilmesidir. Araştırmada hangi dokümanların kullanılacağı önemlidir ve veri kaynağı olarak kullanılabilmesi çalışmanın problemiyle ilgilidir. Doküman inceleme, belli bir amaca uygun olarak dokümanlara ulaşma, orijinal olup olmadığını kontrol etme, dokümanları anlama, veriyi analiz etme, veriyi kullanma aşamalarından oluşmaktadır (Yıldırım ve Şimşek, 2018).

Bu aşamalara göre ilk olarak yabancı dil olarak Türkçe öğretiminde kullanılan ve çalışmanın veri kaynağ 1 olan ders kitabına ulaşılmıştır. Ders kitabında yer alan metinlerin uyarlanmış olup olmadıkları asıllarına ulaşılarak belirlenmiştir. Assıllarına ulaşılabilen metinler, metin değerlendirme aracına göre incelenmiştir.

\section{Verilerin Toplanması}

$\mathrm{Bu}$ çalışmada Türkçenin yabancı dil olarak öğretimi üzerine hazırlanmış olan Yeni Hitit Yabancılar İçin Türkçe B1 öğretim setindeki uyarlanmış metinlerin uyarlanma durumlarını incelemek amacıyla öncelikle metin uyarlama ölçütleri araştırılmış ve metin değerlendirme aracı oluşturulmuştur. Yabancı dil olarak Türkçe öğretiminde yaygın olarak kullanılan Yeni Hitit Yabancılar İçin Türkçe B1 öğretim setindeki uyarlanmış metinler belirlenmiş ve bu metinlerin kaynakçada belirtilen adreslerinden asıllarına ulaşılmıştır. Özgün metin kaynağına ulaşılabilen uyarlanmış metinler çalışmada incelenmek üzere seçilmiştir. Kaynağı belirtilmemiş olan metinler çalışmanın dışında tutulmuştur.

Çalışmada incelenen dokümanlar, yabancı dil olarak Türkçe öğretiminde kullanılan Yeni Hitit Yabancılar İçin Türkçe B1 ders kitabında yer alan "Pazartesi Sendromu", "Erzurum'dan Harvard'a", "Kadın Fanatikler", "Şehirliye anlatmak zor", "Tabiatla geçen çocukluğumuz", "Rahmi Koç’tan Konferans" ve Yeni Hitit Yabancılar İçin Türkçe B1 çalışma kitabında yer alan "En tehlikeli koleksiyon" adlı metinlerdir. Bu metinler uyarlanmış oldukları ve kaynakları belirtildiği için özgün hâllerine de ulaşılabilmiştir.

\section{Verilerin Analizi}

Yabancı dil olarak Türkçe öğretimi ders ve okuma kitapları taranarak belirlenen uyarlanmış metinleri incelemek üzere metin değerlendirme aracı hazırlanmıştır. Sandom'un (2013), Mountford (1976), Anderson ve Davison (1988), Yano, Long ve Ross'un (1994), Kim ve Snow'un (2009) çalışmalarını temel alarak oluşturduğu sadeleştirme ölçütleri ve Siddhartan'ın (2004) çalışmasında belirlediği aşamalar Özmen (2019) tarafından Türkçeye uyarlanarak bir sınıflama oluşturulmuştur. Çalışmada kullanılacak olan metin değerlendirme aracı bu sınıflama doğrultusunda hazırlanmıştır.

Uyarlama ölçütleri incelenirken Yeni Hitit Yabanc1lar İçin Türkçe A1-A2 ve B1 ders kitaplarında yer alan dil bilgisi konuları ve incelenen metinlerde bilindiği varsayılan dil bilgisi yapıları listelenmiştir. Ayrıca sıklığı az ve çok olan kelimelerin değiştirim işlemlerini incelemek için Yeni Hitit Yabancılar İçin Türkçe B1 ders kitabında yer alan kelimeler ve dil bilgisi yapıları da dikkate alınmıştır. Her metin için hedef kitlenin Yeni Hitit Yabancılar İçin Türkçe B1 ders kitabına 
göre öğrendiği dil bilgisi yapıları göz önünde bulundurulmuş ve çalışmada 'düzeye uygunluk' kavramıla ifade edilmiştir.

Metinlerdeki tüm cümleler, Tablo 1'de örneği verilen çizelge doğrultusunda incelenmiş ve karşılaşılan her durum için bir işaret (X) konmuştur. İşaretleme sonunda yapılan işlemler Excel dosyasına işlenerek her maddenin frekans ve yüzde değerleri çıkarılmıştır. Ortaya çıkan sonuçlar tablolar hâlinde sunulmuştur.

Tablo 1: Metin Değerlendirme Aracı

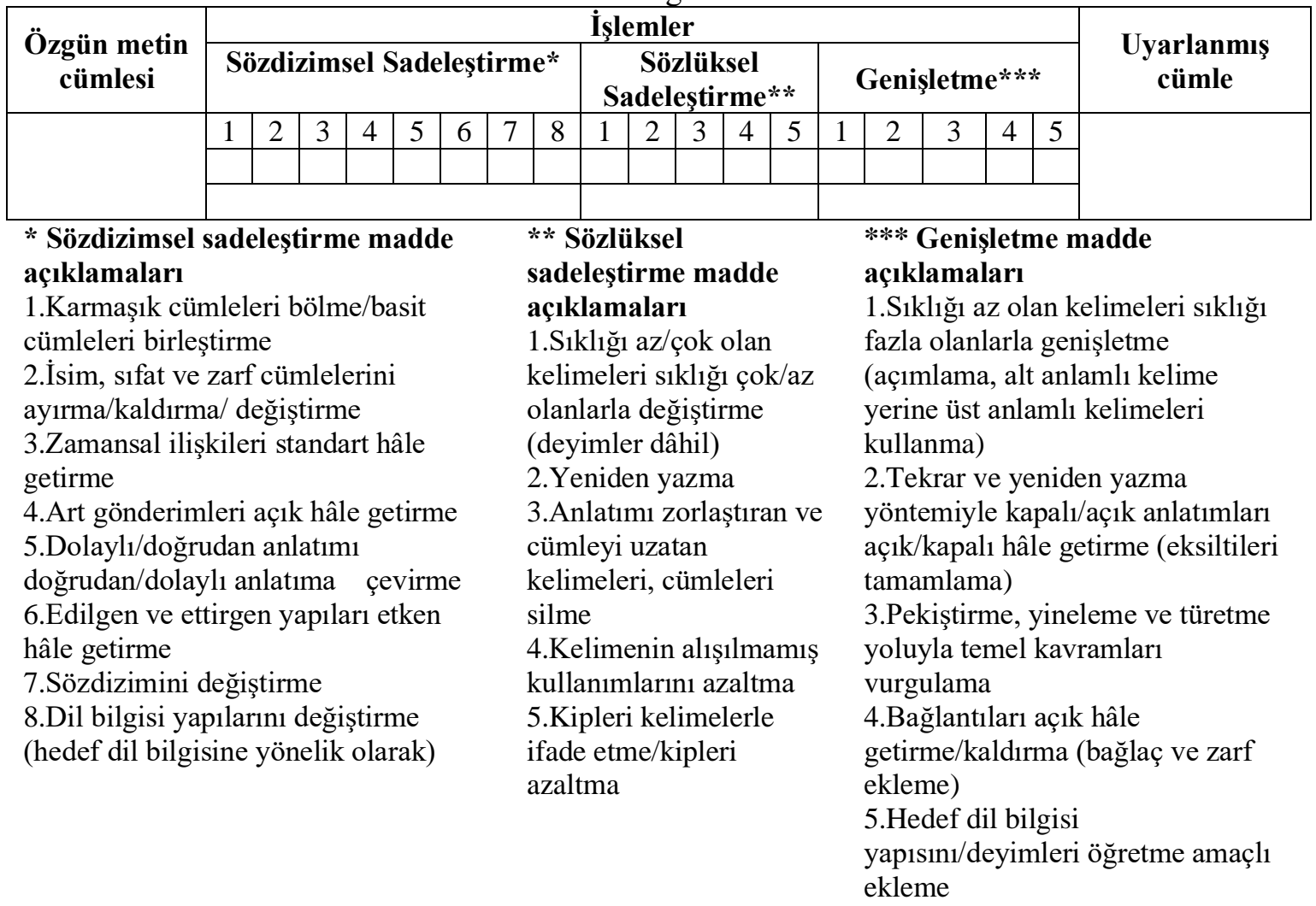

\section{Bulgular}

$\mathrm{Bu}$ bölümde elde edilen bulgular araştırmanın problem ve alt problemleri dikkate alınarak sunulmuştur. Bulguların açıklanmasında tablolardan yararlanılmıştır.

\section{Bulgular}

Metinlerdeki Sözdizimsel Sadeleştirme İşleminin Uygulanma Durumuna Yönelik

Bu başlık altında çalışmanın birinci alt problemi olan uyarlanmış metinlerdeki sözdizimsel sadeleştirme işlemlerinin durumuna ilişkin dağılım Tablo 2'de verilmiştir. 
Tablo 2: Sözdizimsel Sadeleştirme İşleminin Uygulanma Durumuna İlişkin Dağılım

\begin{tabular}{|c|c|c|c|c|c|c|c|c|c|c|c|c|c|c|c|c|c|}
\hline & & \multicolumn{2}{|c|}{ 1. Metin } & \multicolumn{2}{|c|}{ 2. Metin } & \multicolumn{2}{|c|}{ 3. Metin } & \multicolumn{2}{|c|}{ 4. Metin } & \multicolumn{2}{|c|}{ 5. Metin } & \multicolumn{2}{|c|}{ 6. Metin } & \multicolumn{2}{|c|}{ 7. Metin } & \multicolumn{2}{|c|}{ Toplam } \\
\hline & & $\mathrm{F}$ & $\%$ & $\mathrm{~F}$ & $\%$ & $\mathrm{~F}$ & $\%$ & $\mathrm{~F}$ & $\%$ & $\mathrm{~F}$ & $\%$ & $\mathrm{~F}$ & $\%$ & $\mathrm{~F}$ & $\%$ & $\mathrm{~F}$ & $\%$ \\
\hline 1. & $\begin{array}{l}\text { Karmaşık cümleleri } \\
\text { bölme/basit } \\
\text { cümleleri } \\
\text { birleştirme }\end{array}$ & 3 & 25 & 0 & 0 & 0 & 0 & 1 & 25 & 1 & 20 & 1 & 9,1 & 0 & 0 & 6 & 12,5 \\
\hline 2. & $\begin{array}{l}\text { İsim, sıfat ve zarf } \\
\text { cümlelerini ayırma / } \\
\text { kaldırma / } \\
\text { değiştirme }\end{array}$ & 1 & 8,3 & 2 & 40 & 3 & 37,5 & 1 & 25 & 1 & 20 & 2 & 18,2 & 0 & 0 & 10 & 20,8 \\
\hline 3. & $\begin{array}{l}\text { Zamansal ilişkileri } \\
\text { standart hâle } \\
\text { getirme }\end{array}$ & 0 & 0 & 2 & 40 & 1 & 12,5 & 0 & 0 & 0 & 0 & 0 & 0 & 0 & 0 & 3 & 6,3 \\
\hline 4. & $\begin{array}{l}\text { Art gönderimleri } \\
\text { açık hâle getirme }\end{array}$ & 1 & 8,3 & 0 & 0 & 0 & 0 & 0 & 0 & 1 & 20 & 0 & 0 & 0 & 0 & 2 & 4,2 \\
\hline 5. & $\begin{array}{l}\text { Dolaylı/doğrudan } \\
\text { anlatımı doğrudan / } \\
\text { dolaylı anlatıma } \\
\text { çevirme }\end{array}$ & 0 & 0 & 0 & 0 & 0 & 0 & 1 & 25 & 0 & 0 & 4 & 36,4 & 3 & 100 & 8 & 16,7 \\
\hline 6. & $\begin{array}{l}\text { Edilgen ve ettirgen } \\
\text { yapıları etken hâle } \\
\text { getirme }\end{array}$ & 2 & 16,7 & 0 & 0 & 0 & 0 & 0 & 0 & 2 & 40 & 1 & 9,1 & 0 & 0 & 5 & 10,4 \\
\hline 7. & $\begin{array}{l}\text { Sözdizimini } \\
\text { değiştirme }\end{array}$ & 4 & 33,3 & 0 & 0 & 0 & 0 & 1 & 25 & 0 & 0 & 0 & 0 & 0 & 0 & 5 & 10,4 \\
\hline 8. & $\begin{array}{l}\text { Dil bilgisi yapılarını } \\
\text { değiştirme (hedef } \\
\text { dil bilgisine yönelik } \\
\text { olarak) }\end{array}$ & 1 & 8,3 & 1 & 20 & 4 & 50 & 0 & 0 & 0 & 0 & 3 & 27,3 & 0 & 0 & 9 & 18,8 \\
\hline
\end{tabular}

Tablo 2'ye göre sadeleştirilmiş metinlerde toplam 48 tane sözdizimsel sadeleştirme işlemi yapılmıştır. Sözdizimsel sadeleştirmenin en fazla yapıldığı metinler ise 1. metin $(F=12)$ ve 6 . Metin $(\mathrm{F}=11)$ olmuştur. Ayrıca sözdizimsel sadeleştirme işlemlerinden isim/sıfat ve zarf cümlelerini ayırma/kaldırma/değiştirme işlemi $(\mathrm{F}=10)$ en fazla, art gönderimleri açık hâle getirme işlemi $(\mathrm{F}=2)$ uyarlanmış metinlerde en az yapılan işlemdir. En fazla yapılan işlem olan isim/sıfat ve zarf cümlelerini ayırma/kaldırma/değiştirme işleminin yalnızca 7. metinde uygulanmadığı görülmüştür. En az yapılan art gönderimleri açık hâle getirme işlemi ise sadece 1 . metin $(F=1)$ ve 5 . metinde $(F=1)$ uygulanmıştır. Sözdizimsel sadeleştirme içerisinde yer alan tüm sözdizimsel alt işlemlerin yapıldığı bir metin bulunmamaktadır. 1. metin en fazla alt işleme (6) başvurularak oluşturulurken, 7. metin sadece 1 alt işleme başvurularak en az işlemle oluşturulmuştur.

1. metinde toplam 12 tane sözdizimsel işlem yapılmıştır. 1. metin sözdizimsel sadeleștirme işleminin en çok uygulandığ metindir. Sözdizimini değiştirme işlemi 1. metinde $(F=4)$ en fazla yapılan işlemdir. Karmaşık cümleleri bölme/basit cümleleri birleştirme işlemi 3, isim/sıfat ve zarf cümlelerini ayırma/kaldırma/değiştirme işlemi 1, art gönderimleri açık hâle getirme işlemi 1, edilgen ve ettirgen yapıları etken hâle getirme işlemi 2 ve dil bilgisi yapılarını değiştirme (hedef dil bilgisine yönelik olarak) işlemi 3 tane yapılmıştır. Zamansal ilişkileri standart hâle getirme işlemi ve doğrudan/dolaylı anlatımları dolaylı/doğrudan anlatıma çevirme işlemlerinin 1 . metinde uygulanmadığı belirlenmiştir. İşlem çeşitliliği açısından en fazla sözdizimsel işlemin uygulandığı metin olduğu belirlenmiştir. 
2. metinde toplam 5 tane sözdizimsel sadeleştirme işlemi gerçekleştirilmiştir. İsim/sıfat ve zarf cümlelerini ayırma/kaldırma/değiştirme işlemi 2, zamansal ilişkileri standart hâle getirme işlemi 2 ve dil bilgisi yapılarını değiştirme işlemi 1 tane uygulanmıştır. Karmaşı cümleleri bölme/basit cümleleri birleştirme, art gönderimleri açık hâle getirme, doğrudan/dolaylı anlatımları dolaylı/doğrudan anlatıma çevirme, edilgen ve ettirgen yapıları etken hâle getirme ve sözdizimini değiştirme işlemlerinin 2. metinde yapılmadığı görülmüştür.

3. metinde toplam 8 tane sözdizimsel sadeleştirme işlemine başvurulmuştur. Bu metinde en fazla uygulanan işlem dil bilgisi yapılarını değiştirme $(\mathrm{F}=4)$ işlemidir. İsim/sıfat ve zarf cümlelerini ayırma/kaldırma/değiştirme işlemi 3 ve zamansal ilişkileri standart hâle getirme işlemi 1 tanedir. Karmaşık cümleleri bölme/basit cümleleri birleştirme, art gönderimleri açı hâle getirme doğrudan/dolaylı anlatımları dolaylı/doğrudan anlatıma çevirme, edilgen ve ettirgen yapıları etken hâle getirme, sözdizimini değiştirme ve dil bilgisi yapılarını değiştirme işlemlerine hiç başvurulmamıştır. 2. ve 3. metinde aynı sözdizimsel alt işlemler uygulanmıştır.

4. metinde toplam 4 tane sözdizimsel işlem uygulandığ 1 görülmüştür. Karmaşık cümleleri bölme/basit cümleleri birleștirme 1 , isim/sıfat ve zarf cümlelerini ayırma/kaldırma/değiştirme 1 , doğrudan/dolaylı anlatımları dolaylı/doğrudan anlatıma çevirme 1 ve sözdizimini değiştirme işlemi 1 tane yapılmıştır.

5. metinde toplam 5 tane sözdizimsel işlem yapılmıştır. Edilgen ve ettirgen yapıları etken hâle getirme işlemi $(\mathrm{F}=2)$ en fazla yapılan işlemdir. Diğer işlemler; karmaşık cümleleri bölme/basit cümleleri birleştirme 1, isim/sıfat ve zarf cümlelerini ayırma/kaldırma/değiştirme 1 ve art gönderimleri açık hâle getirme işlemi 1 tane yapılmıştır. Ayrıca 5. metin tüm uyarlanmış metinlerde en az uygulanan işlemlerden biri olan artgönderimleri açık hâle getirme işleminin en çok uygulandığı iki metinden biridir.

6. metinde toplam 11 tane işlem yapıldığı görülmektedir. En fazla yapılan işlem ise doğrudan/dolaylı anlatımları dolaylı/doğrudan anlatıma çevirme işlemi $(\mathrm{F}=4)$ olmuştur. İşlem çeşitliliği açısından 5 farklı sözdizimsel işleme başvurulmasıyla 2. sırada yer almaktadır.

7. metinde ise toplam 3 sözdizimsel işleme başvurulduğu belirlenmiştir. Bu işlemler yalnızca doğrudan/dolaylı anlatımları dolaylı/doğrudan anlatıma çevirme işlemine yönelik olmuştur. $\mathrm{Bu}$ metinde diğer işlemlere başvurulmamıştır. En fazla yapılan işlem olma özelliği taşıyan isim/sıfat ve zarf cümlelerini ayırma/kaldırma/değiştirme işlemi tüm metinlerde yapılırken yalnızca 7 . metinde yapılmamıştır.

\section{Bulgular \\ Metinlerdeki Sözlüksel Sadeleştirme İşleminin Uygulanma Durumuna Yönelik}

Bu başlık altında çalışmanın ikinci alt problemi olan uyarlanmış metinlerdeki sözlüksel sadeleştirme işlemlerinin durumuna ilişkin dağılım Tablo 3'te verilmiştir. 
Tablo 3: Sözlüksel Sadeleştirme İşleminin Uygulanma Durumuna İlişkin Dağılım

\begin{tabular}{|c|c|c|c|c|c|c|c|c|c|c|c|c|c|c|c|c|c|}
\hline & & \multicolumn{2}{|c|}{ 1. Metin } & \multicolumn{2}{|c|}{ 2. Metin } & \multicolumn{2}{|c|}{ 3. Metin } & \multicolumn{2}{|c|}{ 4. Metin } & \multicolumn{2}{|c|}{ 5. Metin } & \multicolumn{2}{|c|}{ 6. Metin } & \multicolumn{2}{|c|}{ 7. Metin } & \multicolumn{2}{|c|}{ Toplam } \\
\hline & & $\mathrm{F}$ & $\%$ & $\mathrm{~F}$ & $\%$ & $\mathrm{~F}$ & $\%$ & $\mathrm{~F}$ & $\%$ & $\mathrm{~F}$ & $\%$ & $\mathrm{~F}$ & $\%$ & $\mathrm{~F}$ & $\%$ & $\mathrm{~F}$ & $\%$ \\
\hline & $\begin{array}{l}\text { Siklığı az / çok } \\
\text { olan kelimeleri } \\
\text { sıklığı çok/az } \\
\text { olanlarla } \\
\text { değiştirme } \\
\text { (deyimler dâhil) }\end{array}$ & 4 & 16 & 0 & 0 & 1 & 10 & 4 & 14,3 & 0 & 0 & 7 & 46,7 & 1 & 11,1 & 17 & 16 \\
\hline 2. & Yeniden yazma & 3 & 12 & 2 & 16,7 & 0 & 0 & 8 & 28,6 & 3 & 42,9 & 4 & 26,7 & 1 & 11,1 & 21 & 19,8 \\
\hline 3. & $\begin{array}{l}\text { Anlatımı } \\
\text { zorlaştıran ve } \\
\text { cümleyi uzatan } \\
\text { kelimeleri, } \\
\text { cümleleri silme }\end{array}$ & 13 & 52 & 8 & 66,7 & 8 & 80 & 15 & 53,6 & 4 & 57,1 & 4 & 26,7 & 6 & 66,7 & 58 & 54,7 \\
\hline & $\begin{array}{l}\text { Kelimenin } \\
\text { alışılmamış } \\
\text { kullanımlarını } \\
\text { azaltma }\end{array}$ & 4 & 16 & 2 & 16,7 & 1 & 10 & 1 & 3,6 & 0 & 0 & 0 & 0 & 1 & 11,1 & 9 & 8,5 \\
\hline 5. & $\begin{array}{l}\text { Kipleri } \\
\text { kelimelerle ifade } \\
\text { etme/kipleri } \\
\text { azaltma }\end{array}$ & 1 & 4 & 0 & 0 & 0 & 0 & 0 & 0 & 0 & 0 & 0 & 0 & 0 & 0 & 1 & 0,9 \\
\hline & Toplam: & 25 & 100 & 12 & 100 & 10 & 100 & 28 & 100 & 7 & 100 & 15 & 100 & 9 & 100 & 106 & 100 \\
\hline
\end{tabular}

Tablo 3'te de görüldüğ̈̈ gibi sadeleştirilmiş metinlerde toplam 106 tane sözlüksel sadeleştirme işlemi gerçekleştirilmiştir. Sözlüksel sadeleştirme işleminin en fazla yapıldığı metin 4. metin $(\mathrm{F}=28)$ olmuştur. En az yapılan işlemin ise 5. metin $(\mathrm{F}=7)$ olduğu görülmektedir. Bunun yanı sıra sözlüksel sadeleştirme işlemlerinden anlatımı zorlaştıran ve cümleyi uzatan kelimeleri, cümleleri silme işlemi (58) en fazla, kipleri kelimelerle ifade etme/kipleri azaltma işlemi ( $\mathrm{F}=1)$ ise en az yapılan işlem olma özelliği taşımaktadır. En fazla uygulanan işlem olan anlatımı zorlaştıran ve cümleyi uzatan kelimeleri, cümleleri silme işlemine tüm uyarlanmış metinlerde başvurulduğu, en az uygulanan kipleri kelimelerle ifade etme/kipleri azaltma işleminin ise yalnızca 1. metinde uygulandığ belirlenmiştir.

Uyarlanmış metinlerin tümünde hiç yapılmamış olan sözlüksel sadeleştirme işlemi bulunmamaktadır. Kipleri kelimelerle ifade etme/kipleri azaltma işlemine sadece 1. metinde başvurulmuş olduğu görülmektedir. Bununla beraber yeniden yazma işlemine ise yalnızca 3. metinde başvurulmamıştır.

1. metinde yapılan sözlüksel sadeleştirme işlem sayısı toplam $25^{\prime}$ tir ve hiç uygulanmayan işlem bulunmamaktadır. Bu metinde en çok uygulanan işlem ise tüm metinlerde en çok uygulanan işlem olan, anlatımı zorlaştıran ve cümleyi uzatan kelimeleri, cümleleri silme $(\mathrm{F}=13)$ işlemidir. En az uygulanan işlemin de aynı şekilde tüm metinlerde en az uygulanan işlem olduğu görülmektedir. Sıklığı az/çok olan kelimeleri sıklığı çok/az olanlarla değiştirme 4, kelimenin alışılmamış kullanımlarını azaltma 4 ve kipleri kelimelerle ifade etme/kipleri azaltma işlemi 1 tane uygulanmıştır.

2. metinde gerçekleştirilen sözlüksel sadeleştirme işlem sayısının 12 olduğu görülmektedir. Bu metinde üç farklı işlem gerçekleştirilmiştir. S1klığı az/çok olan kelimeleri sıklığı çok/az olanlarla değiştirme ve kipleri kelimelerle ifade etme/kipleri azaltma işlemleri ise hiç uygulanmamıştır. Anlatımı zorlaştıran ve cümleyi uzatan kelimeleri, cümleleri silme işlemi $(\mathrm{F}=8)$ en fazla uygulanan 
işlemdir. Yeniden yazma $(\mathrm{F}=2)$ ve kelimenin alışılmamış kullanımlarını azaltma $(\mathrm{F}=2)$ işlemleri aynı miktarda yapılmıştır.

3. metinde toplam 10 tane sözlüksel sadeleştirme işlemi yapıldığı belirlenmiştir. En fazla yapılan işlemin ise anlatımı zorlaştıran ve cümleyi uzatan kelimeleri, cümleleri silme işlemi olduğu görülmüştür. Yeniden yazma ve kipleri kelimelerle ifade etme/kipleri azaltma işlemleri hiç yapılmamıştır. Sıklığı az/çok olan kelimeleri sıklığı çok/az olanlarla değiştirme $(\mathrm{F}=1)$ ve kelimenin alışılmamış kullanımlarını azaltma işlemi $(\mathrm{F}=1)$ aynı oranda yapılmıştır. Ayrıca tüm metinlerde yeniden yazma işlemine başvurulurken 3 . metinde başvurulmamıştır.

4. metin 28 tane işlemin gerçekleştirilmesiyle en fazla sözlüksel sadeleştirme işlemi uygulanan metin olmuştur. Tüm metinlerde en fazla gerçekleştirilen alt işlem olan anlatımı zorlaştıran ve cümleyi uzatan kelimeleri, cümleleri silme işleminin 4. metinde ( $F=15)$ en yüksek oranda gerçekleştirildiği görülmektedir. Kipleri kelimelerle ifade etme/kipleri azaltma işlemi ise hiç gerçekleştirilmemiştir. Siklığı az/çok olan kelimeleri sıklığ çok/az olanlarla değiştirme 4, yeniden yazma 8 ve kelimenin alışılmamış kullanımlarını azaltma işlemi 1 tane gerçekleştirilmiştir.

5. metinde toplam 7 sözlüksel işleme başvurulmuştur. Yeniden yazma $(F=3)$ ve anlatımı zorlaştıran ve cümleyi uzatan kelimeleri, cümleleri silme $(\mathrm{F}=4)$ işlemi olmak üzere yalnızca iki sözlüksel alt işleme başvurulduğu görülmektedir. En az sözlüksel işlem uygulanan metin olma özelliği taşımaktadır.

6. metinde üç alt işlemin yapıldığı belirlenmiştir. Toplam işlem sayısı ise 15 'tir. En fazla uygulanan işlem kipleri kelimelerle ifade etme/kipleri azaltma işlemi $(\mathrm{F}=7)$ işlemidir. Yeniden yazma $(\mathrm{F}=4)$ ve anlatımı zorlaştıran ve cümleyi uzatan kelimeleri, cümleleri silme $(\mathrm{F}=4)$ işlemleri ise aynı miktarda yapılmıştır.

7. metinde sadece kipleri kelimelerle ifade etme/kipleri azaltma işleminin uygulanmadığ belirlenmiştir. Toplam sözlüksel sadeleştirme işlem sayısı ise 9'dur. S1klığ az/çok olan kelimeleri sıklığ kullanımlarını azaltma $(\mathrm{F}=1)$ işlemleri uygulanan diğer işlemlerdir.

\section{Metinlerdeki Genişletme İşleminin Uygulanma Durumuna Yönelik Bulgular}

Bu başlık altında çalışmanın üçüncü alt problemi olan uyarlanmış metinlerdeki sözdizimsel sadeleştirme işlemlerini durumuna iliş̧in dağılım Tablo 4 'te verilmiştir. 
Tablo 4: Genişletme İşleminin Uygulanma Durumuna İlişkin Dağılım

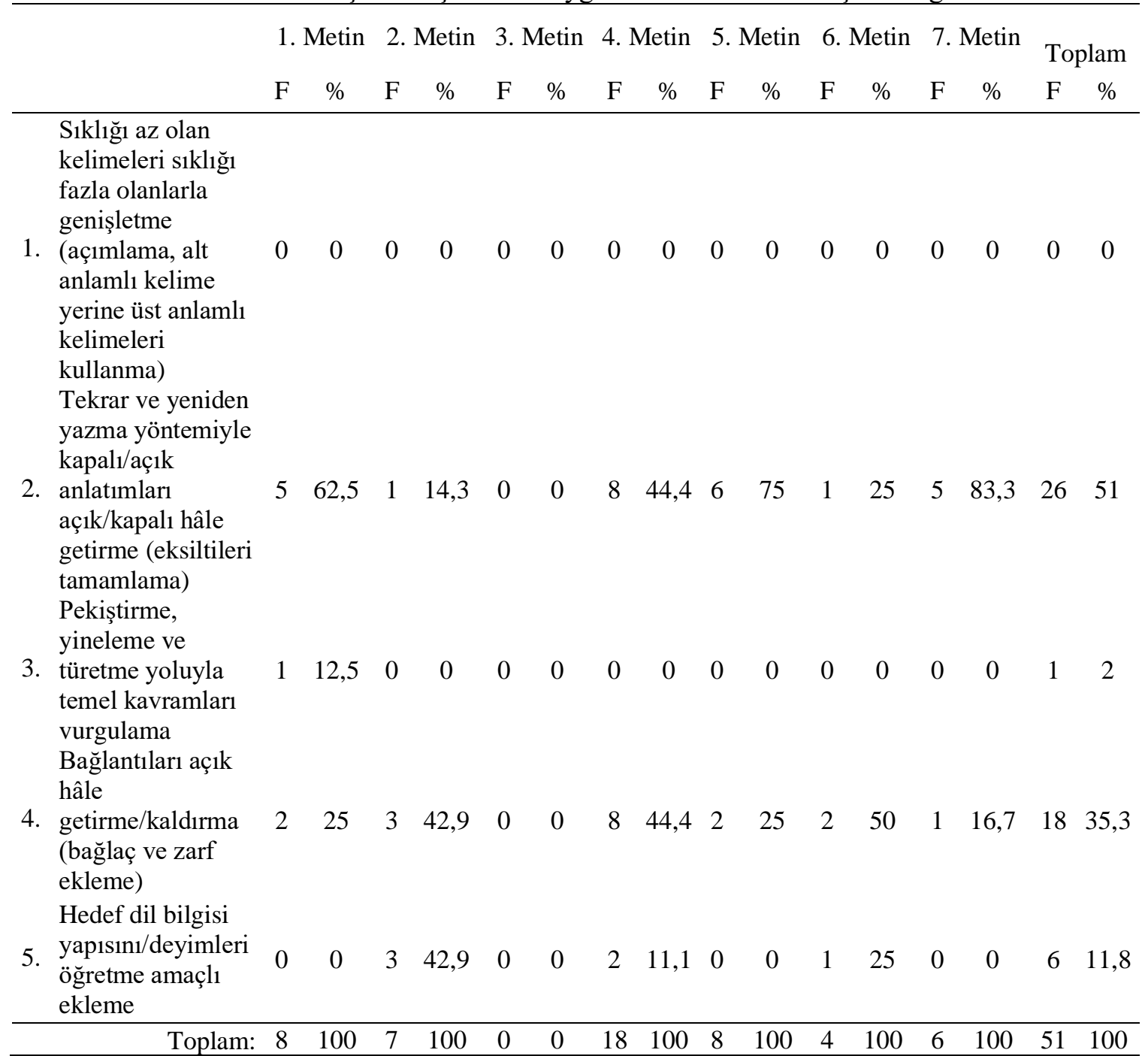

Tablo 4 incelendiğinde sadeleştirilmiş metinlerde toplam 51 tane işlem yapıldığ 1 görülmektedir. Genişletme işleminin en fazla yapıldığı metin 4. metin $(F=18)$ olmuştur. 3. metinde genişletme işlemine hiç başvurulmamıştır. Bununla birlikte genişletme işlemlerinden tekrar ve yeniden yazma yöntemiyle kapalı/açık anlatımları açık/kapalı hâle getirme işlemi $(\mathrm{F}=26)$ tüm metinlerde en fazla uygulanan işlem, pekiştirme, yineleme ve türetme yoluyla temel kavramları vurgulama işlemi $(\mathrm{F}=1)$ en az uygulanan işlemdir. S1klığ 1 az olan kelimeleri sıklığ fazla olanlarla genişletme (açımlama, alt anlamlı kelime yerine üst anlamlı kelime kullanma) işleminin uyarlanmış metinlerde uygulanmadığı görülmüştür.

1. metinde toplam 8 tane genişletme işlemi yapılmıştır. S1klığı az olan kelimeleri sıklığı fazla olanlarla genişletme ve hedef dil bilgisi yapısını/deyimleri öğretme amaçlı ekleme işleminin yapılmadığ 1 görülmektedir. Tekrar ve yeniden yazma yöntemiyle kapalı/açık anlatımları açı/kapalı hâle getirme işlemi $(\mathrm{F}=5)$ en fazla yapılan işlemdir. Pekiştirme, yineleme ve türetme yoluyla temel kavramları vurgulama işlemi diğer metinlerde yapılmamıştır. Ancak bu metinde 1 tane yapıldığ belirlenmiştir. Bağlantıları açık hâle getirme/kaldırma (bağlaç ve zarf ekleme) işlemi 2 tane yapılmıştır. 
2. metinde toplam 7 tane genişletme işlemine başvurulmuştur. Tekrar ve yeniden yazma yöntemiyle kapalı/açık anlatımları açık/kapalı hâle getirme işlemi 1, bağlantıları açık hâle getirme/kaldırma (bağlaç ve zarf ekleme) işlemi 3 ve hedef dil bilgisi yapısını/deyimleri öğretme amaçlı ekleme işlemi 3 tane yapılmıştır.

3. metinde genişletme işlemi yapılmamıştır. Dolayısıyla tüm uyarlanmış metinlerde en fazla uygulanan işlem olan yeniden yazma işleminin yalnızca 3. metinde yapılmadığ 1 tespit edilmiştir.

4. metin tüm metinler arasında en çok genişletme işlemi yapılan metindir. Toplam 18 tane işlem uygulanmıştır. Tekrar ve yeniden yazma $(\mathrm{F}=8)$ ve bağlantıları açık hâle getirme/kaldırma (bağlaç ve zarf ekleme) işlemi $(\mathrm{F}=8)$ aynı miktarda uygulanmıştır. Hedef dil bilgisi yapısını/deyimleri öğretme amaçlı ekleme işlemi 2 tane yapılmıştır. Sıklığı az olan kelimeleri sıklığı fazla olanlarla genişletme ve pekiştirme, yineleme ve türetme yoluyla temel kavramları vurgulama işlemlerine hiç başvurulmamıştır.

5. metinde en fazla uygulanan işlem tekrar ve yeniden yazma yöntemiyle kapalı/açık anlatımları açık/kapalı hâle getirme $(\mathrm{F}=6)$ işlemidir. Bağlantıları açık hâle getirme/kaldırma (bağlaç ve zarf ekleme) ve hedef dil bilgisi yapısını/deyimleri öğretme amaçlı ekleme işlemleri 2 tane yapılmıştır. Sıklığ1 az olan kelimeleri sıklığ fazla olanlarla genişletme ve pekiştirme, yineleme ve türetme yoluyla temel kavramları vurgulama işlemleri hiç yapılmamıştır. Toplam genişletme işlem sayıs ise 8'dir.

6. metinde toplam 4 tane genişletme işlemi uygulandığ 1 görülmektedir. Tekrar ve yeniden yazma yöntemiyle kapalı/açık anlatımları açık/kapalı hâle getirme işlemi 1, bağlantıları açık hâle getirme/kaldırma (bağlaç ve zarf ekleme) işlemi 2 ve hedef dil bilgisi yapısını/deyimleri öğretme amaçlı ekleme işlemi 1 tane yapılmıştır.

7. metinde en çok yapılan işlem yeniden yazma yöntemiyle kapalı/açık anlatımları açı/k/kapalı hâle getirme $(\mathrm{F}=5)$ işlemidir. Toplamda 6 tane genişletme işlemine başvurulmuştur. Bağlantıları açık hâle getirme/kaldırma (bağlaç ve zarf ekleme) işlemi 1 tane yapılmıştır. Yalnızca 2 alt işleme başvurulduğu görülmektedir.

\section{Sonuç ve Öneriler}

$\mathrm{Bu}$ çalışma Yeni Hitit Yabancılar İçin Türkçe B1 öğretim setinde yer alan uyarlanmış metinlerin belirlenmiş ölçütler doğrultusunda uyarlanma durumlarının incelenmesini amaçlamıştır. Uygulama bölümünde Yeni Hitit Yabancılar İçin Türkçe B1 öğretim setinden seçilmiş olan uyarlanmış metinler, metin uyarlama ölçütlerine dayanılarak incelenmiştir. Belirtilen metin uyarlama ölçütleri ve uygulanan işlemler tablolar hâlinde sunulmuştur. Yapılan işlemlerin frekans ve yüzde değerleri hesaplanarak uyarlanmış metinlerde uygulanan işlemlerin oranları verilmiştir.

1. Uyarlanmış metinlerdeki sözdizimsel sadeleştirmeye ilişkin sonuçlar:

Yeni Hitit Yabancılar İçin Türkçe B1 öğretim setinde yer alan uyarlanmış metinlerdeki sözdizimsel sadeleştirmeye yönelik yapılan işlemlerin tüm metinlerde uygulanma oranının $\% 23,8$ olduğu sonucuna varılmıştır. Sözdizimsel sadeleştirme işlemi uygulanan ana işlemler arasında bu oranla ikinci sırada yer almaktadır.

\section{Sözlüksel sadeleştirme işlemine yönelik sonuçlar:}

Yeni Hitit Yabancılar İçin Türkçe B1 öğretim setinde yer alan uyarlanmış metinlerdeki sözlüksel sadeleştirme işleminin uygulanma oranının \%51,7 olduğu belirlenmiştir. Bu sonuca paralel olarak sözlüksel sadeleştirme işleminin, uygulanan ana işlemler arasında birinci sırada yer aldığı görülmektedir. Dolayısıyla uyarlanmış metinlerde en çok kelime ve kelime gruplarına yönelik işlem uygulandığı sonucuna varılabilir. 
3. Genişletme işleminin tüm metinlerde uygulanmasına yönelik sonuçlara bakıldığında \%24,9 oranında olduğu görülmektedir. Genişletme işleminin Yeni Hitit Yabancılar İçin Türkçe B1 öğretim setinde yer alan metinlerde uygulanan ana işlemler arasında ikinci sırada yer aldığı görülmektedir.

Yapılan uygulamaların oranlarına bakıldığında tüm metinlerde en çok 'sözlüksel sadeleștirme' işleminin yapıldığı sonucuna varılmıştır. 'Sözdizimsel sadeleştirme' ve 'genişletme' işlemlerinin ise hemen hemen aynı oranda olduğu görülmektedir. Sözlüksel sadeleştirme işleminin çokça uygulanmış olması, metinlerde düzey üstü kelime ve kelime gruplarının bulunduğu ve bunları düzeye uygun duruma getirebilmek için ise sözlüksel değiştirim, silme ya da yeniden yazma işlemlerine gerek duyulduğu sonucunu ortaya koymaktadır.

Sonuç olarak yabancı dil olarak Türkçe öğretimi ders ve okuma kitaplarında yer alacak metinlerin, metin seçim kriterlerine uyularak ve bilimsel ölçütlere dayandırılarak oluşturulması gerekir. Ders kitaplarında yer alan metinler, farklı çalışmalarla incelenerek uyarlama çalışmalarında faydalanılacak ortak metin uyarlama ölçütleri belirlenebilir. Bu belirlenecek olan ortak metin uyarlama ölçütlerinin yabancı dil olarak Türkçe öğretimi alanındaki metin uyarlama çalışmalarına katk1 sağlayacağı düşünülmektedir.

Bu araştırmanın sonuçları doğrultusunda benzer çalışmalar yapacak araştırmacılara ve bu tür materyalleri kullanan araştırmacılara şu öneriler sunulabilir:

1. Sadeleştirme veya uyarlama çalışmalarının sistematik bir şekilde bir ölçüt kullanılarak yapılması hedefe uygun ve işlevsel metinlerin ortaya çıkmasını sağlayacaktır.

2. Yabancı dil olarak Türkçe öğretimi başta olmak üzere her türlü ders kitabında yer alan sadeleştirilmiş metinlerin incelenmesi, materyal hazırlayıcılara ve ders kitabı kullanıcılarına yardımcı olacaktır. Bu nedenle araştırmacıların ders kitaplarında yer alan metinleri sadeleştirme ölçütlerine göre inceleyen çalışmalara odaklanmaları önerilir.

\section{Kaynakça}

Ak, D. ve Aksu, C. (2016). Yabancı dil olarak Türkçe okuma öğretimi ve ders malzemeleri. B. Tüfekçioğlu ve F. Yıldırım (Yay. haz.), Yabancı dil olarak Türkçe öğretimi içinde (s.79-96) Pegem Akademi.

Arslan, M. ve Ayhan, S.M. (2014). Edebî metin olarak masalların yabancılara Türkçe öğretiminde dilsel ve kişisel becerilerin gelişimine etkisi. Hitit Üniversitesi Sosyal Bilimler Enstitüsü Dergisi. 7 (2), 543-559.

Berardo, S.A. (2006). The use of authentic materials in the teaching of reading. The Reading Matrix, $6(2), 60-69$.

Bölükbaş, F. (2015). Yabancı dil olarak Türkçe öğretiminde okuma metinlerinin dil düzeylerine göre sadeleștirilmesi. International Journal of Languages' Education and Teaching, 924-935.

Crossley, Scott A., Allen, D., Danielle S. and Mcnamara (2011). Text readabilitiy and intuitive simplification: a comparison of readability formulas, Reading in foreign language 23 (1), 84-102.

Demircan, Ö. (1990). Yabancı dil öğretim yöntemleri. Ekin Yayınları.

Dilidüzgün, Ş. (1995). Yabancı Dil Olarak Türkçe Öğretiminde Yazınsal Metinler. (Yayımlanmamış Yüksek Lisans Tezi). İstanbul Üniversitesi. 
Durmuş, M. (2013). İkinci/Yabancı dil öğretiminde özgün ve değiştirilmiş dilsel girdi üzerine. Turkisch Studies- International Periodical for the Languages, Literature and History of Turkish or Turkic. 8 (1) 1291-1306.

Durmuş M. ve Cihangir S. (2018). Yabancılara Türkçe öğretiminde okuma metinlerinin sadeleştirilmesi. Gazi Üniversitesi yabanc1lara Türkçe öğretim seti örneği. International Journal of Language Academy, 6 (5), 684-694.

Durukan E. ve Bayraktar İ. (2016). Türkçe ders kitaplarında metin sadeleştirme üzerine bir değerlendirme. Uluslararası Türkçe Edebiyat Kültür Eğitim Dergisi, 5 (3), 1356-1369.

Güneş, F. (2013). Türkçe öğretiminde metin seçimi. Ana Dili Ĕgitimi Dergisi, 1 (1), 1-12.

Nurlu, M. ve Kaya, M. (2017). Özgün ve yabancı dil olarak Türkçe öğretimi için sadeleştirilmiş metinlerde fiilimsi kullanımı: Dokuzuncu Hariciye Koğuşu ve Yı1kı Atı Örneği. Turkisch Studies- International Periodical for the Languages, Literature and History of Turkish or Turkic, 12 (28), 325-342.

Özmen, C. (2019). Yabancı dil olarak Türkçe öğretiminde metin değiştirim teknikleriyle öykülerin yeniden oluşturulması. (Yayımlanmamış Doktora Tezi). Hacettepe Üniversitesi Türkiyat Araştırmaları Enstitüsü.

Sandom, M. (2013). Investigation into the efficacy of text modification: What type of text do learners of Japanese authenticate? (Yayımlanmamış Doktora Tezi). Victoria University of Wellington.

Şavlı, F. ve Ermağan, A.E. (2015). Yabancı dil eğitiminde edebi metinler kullanımı. International Journal of Languages, Education and Teaching. 885-893.

Siddhartan, A. (2004). Syntactic simplification and text cohesion. Technical report, University of Cambridge.

Yıldırım, E. ve Şimşek, H. (2018). Sosyal bilimlerde nitel araştırma yöntemleri. Seçkin Yayıncılık.

Y1lmaz, E. (2009). Uygulamalı Metin bilgisi.Pegem Akademi.

Yücel, F ve Erişek, Ö. (2002). Dil öğretiminde yazınsal metinlerin yeri. Osmangazi Üniversitesi, Sosyal Bilimler Dergisi, 3 (2), 63-76.

\section{İnternet Kaynakları}

Camgöz, B. (2013, 28 Mayıs). Tabiatla geçen çocukluğumuz. 12 Nisan 2019 tarihinde www.dünyalilar.org.tr._adresinden erişildi.

Canıdar, S. (2004, 18 Nisan). Tribünlerin sultanları. 16 Nisan 2019 tarihinde www.sabah.com.tr adresinden erişildi.

Haber Vitrini. (2004, 1 Nisan)._Rahmi Koç’tan ilginç sözler: zengin olunca ölemiyorsunuz. 10 Temmuz 2019 tarihinde www.habervitrini.com adresinden erişildi.

Hürriyet (2000, 30 Ocak). En tehlikeli koleksiyon. 13 Mayıs 2019 tarihinde www.hurriyet.com adresinden erişildi.

Pamir, B. (2005, 26 Haziran). Erzurum'dan Harvard'a. Sabah. 15 May1s 2019 tarihinde www.sabah.com.tr adresinden erişildi. 
Tokbaş, Y. (2007, 18 Haziran). Pazartesi sendromu. 2 Haziran 2019 tarihinde www.hurriyet.com.tr adresinden erişildi.

Uhri, M. (2017). Şehirliye anlatması zor. Bütün Dünya, 3, 108-110. 5 Haziran 2019 tarihinde www.sizeedebiyat.com adresinden erişildi. 